\title{
Living with large-scale technology : nuclear reactors in the Touraine in the 1950's and 1960's
}

Gabrielle Hecht

\section{(2) OpenEdition}

12 Journals

Electronic version

URL: https://journals.openedition.org/tc/667

DOI: $10.4000 /$ tc. 667

ISSN: 1952-420X

Publisher

Éditions de l'EHESS

Printed version

Date of publication: 1 May 1993

ISSN: 0248-6016

\section{Electronic reference}

Gabrielle Hecht, "Living with large-scale technology : nuclear reactors in the Touraine in the 1950's and 1960's", Techniques \& Culture [Online], 19 | 1993, Online since 10 January 2006, connection on 29

September 2022. URL: http://journals.openedition.org/tc/667 ; DOI: https://doi.org/10.4000/tc.667

This text was automatically generated on 29 September 2022.

All rights reserved 
Living with large-scale technology: nuclear reactors in the Touraine in the 1950's and 1960's

Gabrielle Hecht 